\author{
Sabadash 5., \\ Savchenko-Pererva M., \\ Radchuk 0., \\ Rozhkova L., \\ Kazakov D., \\ Zahorulko A.
}

\title{
DESIGN DEVELOPMENT OF A CONTINUOUS INDUSTRIAL DRYING PLANT FOR DRYING POMACE OF WALNUTS, PEANUTS AND PISTACHIOS
}

Об'єктом дослідження є процес сушіння вичавок ядра волоського горіху, арахісу та фісташок у сушарuі із псевдозрідженим шаром інертного носія. Одним з найбільш проблемних місць є питання утилізацї вторинних сировинних ресурсів, які являють значний потенціал для харчової промисловості. Вирішення проблеми, яка є нагальною, - че консервування вичавок ядра волоського горіху, арахісу та фісташок для подальшого їх використання в харчовій промисловості. При щьому переваги сушених напівфабрикатів:

- можливість транспортування на великі відстані;

- тривалий термін зберігання сушеної продукцї;

- використання в технології виробництва продуктів харчування;

- використання як білкової добавки.

Тому робота присвячена розробщі нових і модернізацї існуючих способів сушіння. Одним із таких способів є сушіння у псевдозрідженому шарі інертного носія, який для сушіння даного продукту до иього не використовувався через складність перебігу процесу.

В ході дослідження використовувався метод мікроскопічного визначення дисперсного складу продукту, який дозволяє вимірювати частки розміром 0,3-100 мкм. Досліджувані порошки різної дисперсності досліджували за допомогою USB Digital Microscope. Здійснено математичну обробку отриманих результатів з використанням сучасних комп'ютерних програм. Отримані дані були оброблені в середовищі Матһсаd та представлені у вигляді інтегральних та диференціальних функцій розподілу частинок для кожного проаналізованого зразка. Це пов'язано з тим, що аналіз визначення дисперсного складу є обов'язковим методом контролю в усіх технологічних процесах. Завдяки цьому забезпечується можливість отримання заданого розміру продукту. У процесі дослідження розроблено конструкцію промислової сушильної установки безперервної дї для сушіння вичавок ядра волоського горіху, арахісу та фісташок. Запропонований у роботі спосіб сушіння має низку переваг над іншими способами, основними з яких є зниження енерговитрат і підвищення якості готової продукції.

Ключові слова: дисперсний склад, мікроскопічний метод, сушіння продуктів, інтегральна та диференцігальна функція розподілу.

\section{Introduction}

One of the important issues of the food industry is to increase the resources of food protein, improve the technique and technology of processing traditional and non-traditional raw materials in various sectors of the food industry and expand the range of high-grade food [1]. One way to solve the problem of increasing protein resources is to use secondary raw materials [2]. The use in Ukraine of secondary raw materials from food industry enterprises is becoming increasingly important. Large volumes of industrial processing of various raw materials of plant origin for food purposes constitute a significant potential for the agricultural sector [3]. This also applies to oil-fat production. In the production of oil from the walnut kernel, peanuts and pistachios, a large number of squeezes are formed, which are valuable raw materials containing proteins, fats, fiber, ash and vitamins [4]. Dry powders from these products are characterized by a high content of technologically constant protein (48...60\%), low fat $(8 \ldots 20 \%)$ and moisture $(2 \ldots 9 \%)$. Adding dry powders from squeezes into wafer products improves their quality, in particular, their biological value: it ensures the presence of essential amino acids, polysaccharides, unsaturated fatty acids, dietary fiber and other valuable components. The introduction of dry powders from pomace has a positive effect on the organoleptic characteristics of fillings (changes color, gives the finished product a pleasant taste and aroma of nuts) [5,6]. Powdered materials are used in many industries. Many properties of powders are highly dependent on dispersion. Analysis of the dispersed composition is a mandatory control method in all technological processes associated with the manufacture and processing of powdered materials [7-9]. There are several methods for determining the dispersed composition [10, 11]: sieve analysis, sedimentation analysis, hydrodynamic methods, 
and microscopic analysis. In this case, the microscopic method is different in that it allows to determine not only the geometric dimensions of the studied objects, but also to see the features of their shape, structure and surface structure. The microscopic method allows to measure particles with a size of $0.3-100$ microns. To determine the particle size less than 1 micron, electron microscopes with a higher resolution than optical ones are used.

Thus, the object of research is the drying process of the pomace of the walnut kernel, peanuts and pistachios in a fluidized bed dryer with an inert support. The aim of research is determination of the dispersed composition of the powders from the pomace of the walnut kernel, peanuts and pistachios for further use in the food industry.

\section{Methods of research}

During the study, a microscopic method was used to determine the dispersed composition of the powders, which differs in that it allows to determine not only the geometric dimensions of the objects under study, but also to see the features of their shape, structure and surface structure.

Based on the results of laboratory studies, a pilot plant was designed for drying the pomace of the walnut kernel, peanuts and pistachios. Drying took place as follows: drying of the saw material in a direct flow with a gaseous coolant and final drying on the surface of inert materials in a state of fluidization [12-14].

The theoretical and experimental studies made it possible to obtain empirical relations [15, 16] necessary for the engineering calculation of the design features of a dryer with a fluidized bed of an inert drying carrier.

Fig. 1 shows the design of a drying chamber.

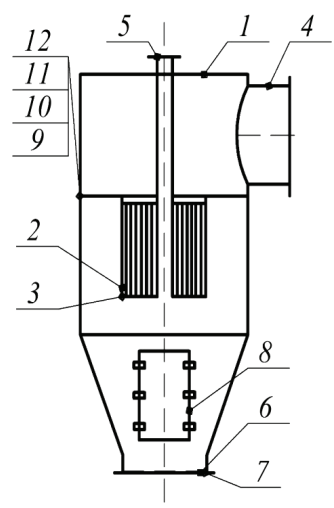

Fig. 1. Cylindroconical drying chamber in a fluidized bed of an inert carrier: 1 - drying chamber; 2 - product trap; 3 - holes; 4 - outlet pipe; 5 - inlet pipe; 6 - gas distribution grill; 7 - coolant inlet; 8 - hatch; 9 - bolts; 10 - nuts; 11 - washer; 12 - gasket

Features of the installation for drying are:

- in the upper part of the chamber there is a device for capturing the product, which prevents the removal of an inert carrier with the particles;

- the use of fluoroplastic chips allows to intensify the drying process due to the increase in the surface of heat and mass transfer;

- the use of a fan and air heater allows to get dry hot air of the required temperature, preventing darkening of the product.

The initial data for the development and creation of the drying installation are given in Table 1.
Table 1

Initial data for the design and construction of a drying plant

\begin{tabular}{|l|c|}
\hline \multicolumn{1}{|c|}{ Raw materials } & $\begin{array}{c}\text { Pomace of walnut kernels, } \\
\text { peanuts and almonds }\end{array}$ \\
\hline Dryer productivity on wet material, $\mathrm{kg} / \mathrm{s}$ & 0.45 \\
\hline $\begin{array}{l}\text { Loading of raw materials and unloading } \\
\text { the product }\end{array}$ & automatic \\
\hline Drying control & auto \\
\hline Air heater control & automatic, electronic \\
\hline The number of staff, people & $3-5$ \\
\hline
\end{tabular}

\section{Research results and discussion}

Using further computer data processing, the integral distribution functions of powder particles are constructed [17, 18] (Fig. 2).
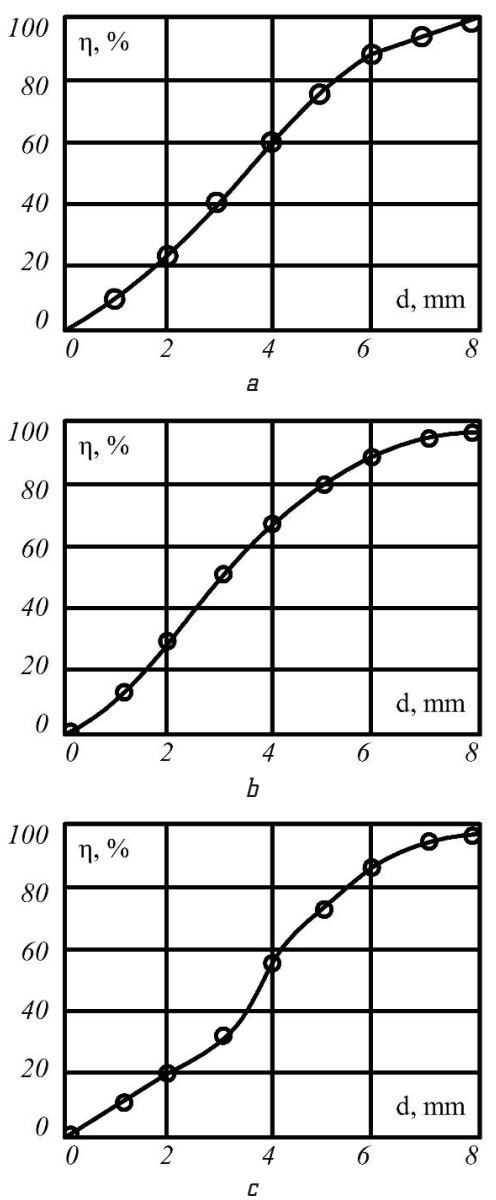

Fig. 2. The integral distribution function for the dried powder from the core pomace: $a$ - peanuts; $b$ - walnut; $c$ - pistachios

Let's begin the construction of the smallest particles, deferring their percentage $\left(Q_{0}\right)$ on the ordinate. Then, for the particles of the next fraction, the ordinate is postponed, equal to the sum of the percentage of particles of the previous fraction and the fraction with a large radius and so on. They work until the last ordinate (corresponding to the maximum diameter) brought $100 \%$.

Further, using the following operations in the environment of the Mathcad program, let's construct differential distribution functions [19] (Fig. 3). 

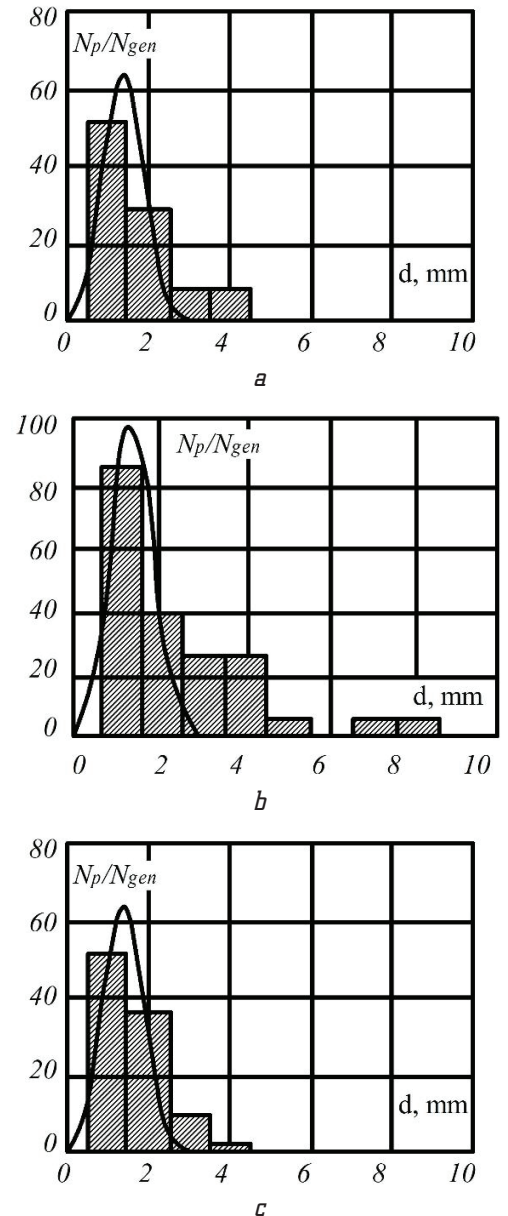

Fig. 3. The differential distribution function against the background of the experimental discrete histogram, indicating the number of particles of various sizes (dried powder from the pomace core: $a$ - peanuts; $b$ - walnut; $c$ - pistachios)

For approximation, functions of the form ore used: - for powders from the walnut kernel pomace:

$a_{0} \cdot x^{a_{1}} \cdot e^{a_{2} \cdot x}$

- for powders from the peanuts kernel pomace:

$a_{0} \cdot x \cdot e^{\left(a_{1} \cdot x+a_{2} \cdot x^{2}\right)}$

- for powders from the pistachios kernel pomace:

$a_{1} \cdot x \cdot e^{a_{0} \cdot a_{2} \cdot x^{2}}$.

As it is possible to see, they completely and accurately describe the experimental data and fall at the experimental maximum, which makes it possible to determine the most probable particle size for a given sample (Fig. 4).

Let's construct differential distribution functions (Fig. 5).

The integral and differential particle size distribution functions of the research product for three model products of different dispersion are described quite accurately by the experimental data in Fig. 5. It is seen that, after drying, distribution curve 1 has a pronounced maximum and a smaller width, since the particles are more uniform in size, while squeezed samples from peanut kernels and pistachios (curves 2, 3, respectively) are characterized by a maximum shift. Obviously, this is due to the fact that large particles of moisture due to partial swelling increase in size, provided that it reflects a certain asymmetry of the curves themselves. So, during drying, this fact should be taken into account, it affects mass transfer, since particles with high dispersion give moisture more easily.

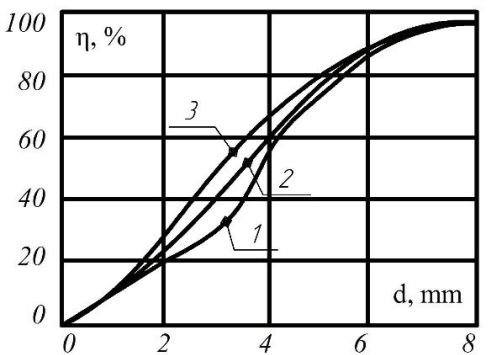

Fig. 4. Integral particle size distribution functions for three model products of different dispersion: 1 - curve for dried pistachios pomace; 2 - curve for dried peanut pomace; 3 - curve for dried walnut pomace

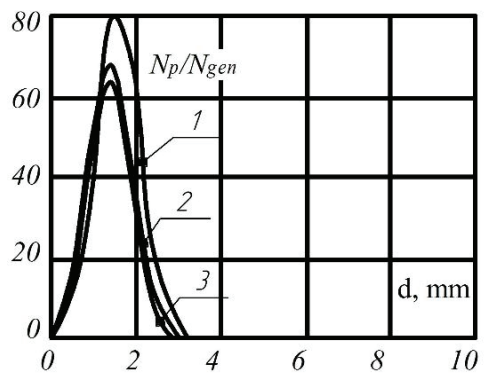

Fig. 5. Differential particle size distribution functions for three model products of different dispersion: 1 - curve for dried walnut pomace; 2 - curve for dried peanut pomace; 3 - curve for dried walnut pomace

\section{Conclusions}

In the process of research, a design of a continuous industrial drying plant for drying pomace of walnut kernels, peanuts and pistachios is developed, for which declarative patents of Ukraine is obtained. The drying method proposed in this work has several advantages over other methods, the main of which are the reduction of energy consumption and improving the quality of the finished product.

\section{References}

1. Kudra, T. (2004). Energy Aspects in Drying. Drying Technology, 22 (5), 917-932. doi: http://doi.org/10.1081/drt-120038572

2. Bezbakh, I. V., Bakhmutyan, N. V. (2006). Issledovanie protsessa sushki plodov i yagod vo vzveshennom sloe. Nauk. pratsi ONAKhT, 2 (28), 60-64.

3. Zagorulko, A., Zahorulko, A., Kasabova, K., Chervonyi, V., Omelchenko, O., Sabadash, S. et. al. (2018). Universal multifunctional device for heat and mass exchange processes during organic raw material processing. Eastern-European Journal of Enterprise Technologies, 6 (1 (96)), 47-54. doi: http://doi.org/ 10.15587/1729-4061.2018.148443

4. Oboznaia, M. V., Shilman, L. Z., Percevoi, N. F., Percevoi, F. V. (2014). Perspektivy razrabotki syrnogo produkta miagkogo s kombinirovannym recepturnym sostavom. Tekhnologiia i produkty zdorovogo pitaniia. Saratov: FGBOU VPO «Saratovskii GAU», 265-267.

5. Pohozhykh, M. I., Potapov, V. O., Tsurkan, M. M. (2008) Tekhnolohiia sushinnia kharchovoi syrovyny. Kharkiv: KhDUKhT, 229.

6. Danilov, I., Leonchik, B. (1986). Ekonomiya energii pri teplovoy sushke. Moscow: Energoatomizdat, 136. 
7. Izli, N., Izli, G., Taskin, O. (2017). Influence of different drying techniques on drying parameters of mango. Food Science and Technology, 37 (4), 604-612. doi: http://doi.org/10.1590/ 1678-457x.28316

8. Yurchenko, V. O., Ponomarov, K. S., Ponomarova, S. D. (2017). Doslidzhennia dyspersnoho skladu pylu kondyterskykh pidpryiemstv. Ekolohichna bezpeka, 2, 32-38.

9. Kouzov, P. A. (1987). Osnovy analiza dispersnogo sostava promyshlennykh pylei i izmelchennykh materialov. Leningrad: Khimiia, 264.

10. Brown, J. S., Gordon, T., Price, O., Asgharian, B. (2013). Thoracic and respirable particle definitions for human health risk assessment. Particle and Fibre Toxicology, 10 (1), 12. doi: http:/ doi.org/10.1186/1743-8977-10-12

11. Rebinder, P. A. (1966). Fiziko-khimicheskaia mekhanika dispersnykh struktur. Moscow: Nauka, 63.

12. Sabadash, S., Kazakov, D., Yakuba, A. (2015). Development of the post-alcohol stillage drying process on inert bodies and output of criterion dependence. Eastern-European Journal of Enterprise Technologies, 1 (6 (73)), 65-70. doi: http://doi.org/ 10.15587/1729-4061.2015.38056

13. Yi, X.-K., Wu, W.-F., Zhang, Y.-Q., Li, J.-X., Luo, H.-P. (2012). Thin-Layer Drying Characteristics and Modeling of Chinese Jujubes. Mathematical Problems in Engineering, 2012, 1-18. doi: http://doi.org/10.1155/2012/386214

14. Ahmad-Qasem, M. H., Santacatalina, J. V., Barrajón-Catalán, E., Micol, V., Cárcel, J. A., García-Pérez, J. V. (2014). Influence of Drying on the Retention of Olive Leaf Polyphenols Infused into Dried Apple. Food and Bioprocess Technology, 8 (1), 120-133. doi: http://doi.org/10.1007/s11947-014-1387-6

15. Burdo, O. G., Burdo, A. C., Sirotyuk, I. V., Pour, D. S. (2017). Technologies of Selective Energy Supply at Evaporation of Food Solutes. Problemele energeticii regionale, 1 (33), 100-109. Available at: http://journal.ie.asm.md/assets/files/12 01 33 2017.pdf

16. Yehorov, V., Golubkov, P., Putnikov, D., Honhalo, V., Habuiev, K. (2019). System for analyzing the qualitative characteristics of grain mixes in real time mode. Food Science and Technology, 12 (4). doi: http://doi.org/10.15673/fst.v12i4.1222
17. Peltola, J. (2009). Dynamics in a Circulating Fluidized Bed: Experimental and Numerical Study. Tampere, 95.

18. Kirianov, D. V., Kirianova, E. N. (2006). Vychislitelnaia fizika. Moscow: Polibuk Multimedia, 352.

19. Maksfild, B. (2010). Mathcad v inzhenernykh raschetakh. Moscow: KORONA-Vek: MK-Press, 304

Sabadash Sergei, PhD, Associate Professor, Department of Engineering Technology of Food Production, Sumy National Agrarian University, Ukraine, ORCID: http://orcid.org/0000-0002-0371-8208, e-mail: s.v.sabadash@ukr.net

Savchenko-Pererva Marina, PhD, Associate Professor, Department of Engineering Technology of Food Production, Sumy National Agrarian University, Ukraine, ORCID: http://orcid.org/0000-00018813-9303, e-mail: marina.savchenko-pererva@snau.edu.ua

Radchuk Oleg, PhD, Associate Professor, Department of Engineering Technology of Food Production, Sumy National Agrarian University, Ukraine, ORCID: http://orcid.org/0000-0002-8228-2499, e-mail: oleg.radchuk@snau.edu.ua

Rozhkova Lyudmila, PhD, Associate Professor, Department of Engineering Technology of Food Production, Sumy National Agrarian University, Ukraine, ORCID: http://orcid.org/0000-0002-1068-8959, e-mail: rozhkova_lg@ukr.net

Kazakov Dmytro, Senior Lecturer, Department of Engineering Technology of Food Production, Sumy National Agrarian University, Ukraine, ORCID: http://orcid.org/0000-0002-1750-8578, e-mail: sms.kazak.dd@ukr.net

Zahorulko Andreii, PhD, Senior Lecturer, Department of Processes, Devices and Automation of Food Production, Kharkiv State University of Food Technology and Trade, Ukraine, ORCID: http:// orcid.org/0000-0001-7768-6571,e-mail:zagorulkoAN@hduht.edu.ua 